\title{
Analysis of Mathematical Problem-Solving Ability of Class XI Senior High School Students on Sequences and Series Materials
}

\author{
Resi Erni
}

Universitas Riau, INDONESIA

\section{ARTICLE'S \\ INFORMATION}

\section{Article history:}

Received: Jun-05-2021

Reviewed: Jun-21-2021

Accepted: Jun-28-2021

$\begin{array}{lr}\text { Keywords: } & \text { Analysis, } \\ \text { Mathematical } & \text { Problem- } \\ \text { Solving Ability, } & \text { Sequences } \\ \text { and Series } & \end{array}$

\section{Corresponding address:}

Resi Erni,

E-mail: resi.erni1744@grad.unri.ac.id

\begin{abstract}
The objective of this study was to analyze the mathematical problem-solving abilities of class XI high school students in solving sequence and series questions. This research is a descriptive study that aims to describe the mathematical problemsolving ability of class XI students in solving problems of sequences and series. The population in this study were students of class XI SMA in the academic year 2020/2021. The sample was selected by purposive sampling obtained students XI MIPA 1 totaling 25 students. The data was obtained from the results of the mathematical problem-solving ability essay test on the material of sequences and series as many as 4 questions taken from the 2018 National Examination questions. The purpose of this study was to determine and analyze students' mathematical problem-solving abilities on the material of sequences and series. From the results of the study, it can be concluded that the mathematical problem-solving ability on indicators 1, 2, and 3 are categorized as medium and high. In accordance with the research method, students are categorized as having low mathematical problemsolving abilities if they obtain medium, high, and very high criteria. The percentage of indicator 1 is $68.75 \%$, the percentage of indicator 2 is $55.75 \%$, the percentage of indicator 3 is $62.2 \%$ while the percentage of indicator 4 is 34.75 .
\end{abstract}

\section{INTRODUCTION}

Mathematics is a branch of science that plays an essential role in the development of Science and Technology (IPTEK) and to solve problems in everyday life or contextual problems. This is in line with [1] which says that along with the increasing development of science and technology, mathematics has an important role as basic science. Because of this role, mathematics is studied at every level starting from the elementary school level, up to a higher level. It aims to equip students with the ability to think logically, analytically, systematically, critically, and creatively. In addition, students are required to be able to develop mathematical skills in problem-solving and communicating ideas using symbols, tables, diagrams, and other media.

Based on Permendikbud Number 22 of 2016 concerning the objectives of learning mathematics which expects students to: (a) understand mathematical concepts, describe how the interrelationships between mathematical concepts and apply concepts or logarithms efficiently, flexible, accurate, and precise in solving problems, (b) reasoning patterns the nature of mathematics, developing or manipulating mathematics in formulating arguments, formulating evidence, or describing mathematical arguments and statements, (c) solve mathematical problems which include the ability to understand problems, develop mathematical models of completion, complete mathematical models, and provide appropriate solutions, and (d) communicate arguments or ideas with diagrams, tables, symbols, or other media in order to clarify the problem or situation. Thus, there are five things 
that must be mastered or possessed by students after studying mathematics.

The purpose of learning mathematics is also stated in Permendikbud number 58 concerning Guidelines for Mathematics Subjects and Permendikbud number 21 regarding content standards including using thinking and reasoning skills in problem-solving. This shows that the objectives of learning mathematics have been in line with the achievement of competencies or life skills in the future. Therefore, students' mathematical problem-solving skills need to be improved. Meanwhile, the purpose of mathematics in schools according to [2] is for students to be able to: understand mathematical concepts, explain the interrelationships between concepts; use reasoning on patterns and traits, perform mathematical manipulations in making generalizations, construct proofs, or explain mathematical ideas and statements; solve mathematical problems; communicate ideas with symbols, tables, diagrams, or other media to clarify the situation or problem; have an attitude of appreciating the usefulness of mathematics in life.

The purpose of learning mathematics implies that learning mathematics is focused on training students' ability to communicate and solve mathematical problems in everyday life. The ability to communicate and solve mathematical problems includes the ability to communicate mathematical ideas, understand problems, design mathematical models, complete mathematical models, and interpret the solutions obtained. So that, with this it can achieve maximum learning goals. Because when students do communication, especially written communication, it is also at the same time, they solving problems.

In [3] stated that problem-solving ability is a process of applying previously acquired knowledge in new and different situations. In general, according to [4] the objectives of teaching problem-solving are to (1) build new mathematical knowledge, (2) solve problems that arise in mathematics and in other contexts, (3) apply and adapt various appropriate strategies to solve problems, and (4) monitor and reflect on the mathematical problem-solving process.

Mathematics learning should prioritize the ability to think systematically, critically, and problem-solving skills according to [5]. This is as stated in [6] that problem-solving skills are very important in mathematics, not only for those who later study or study mathematics but also for those who will apply it in other fields of study and in everyday life. Therefore, students must always be trained and accustomed to think independently in solving problems. Because, learning mathematics is expected to train students' abilities that are more useful to overcome the problems they face in the future which is full of very tight competition.

The results of research related to problem-solving according to [7] showing that problemsolving strategies that are generally learned in mathematics, in certain cases, can be transferred and applied in other problem-solving situations. Problem-solving ability is closely related to students' ability to read and understand the language of story questions, present in mathematical models, plan calculations from mathematical models, and complete calculations from non-routine questions. In line with the opinion [8] which states that problem-solving must be based on the cognitive structure of the students, if not based on the cognitive structure only a few students can solve the problems presented. Thus, the cognitive structure of students can show that problem-solving abilities can help students develop intellectual skills and work on how to solve problems using problem-solving steps.

One of the studies that is of great concern to academics, practitioners, and observers of mathematics education is the results of Trends in International Mathematics and Science Study (TIMSS). The results of the TIMSS report according to [9] in 1999 Indonesia was ranked 34th out of 38 countries. Then in 2003, Indonesia was ranked 35th out of 46 countries, in 2007 Indonesia was ranked 36th out of 49 countries while in 2011 Indonesia was ranked 38th out of 42 countries. This is 
evidence that Indonesia is still low in problem-solving ability. The low mathematical problem-solving ability of students is generally caused by students not understanding the problem given because students are not accustomed to working on a problem in accordance with the correct and appropriate steps or procedures.

Besides TIMSS, PISA is a study of international assessment programs organized by the OECD. PISA is conducted once in three years, the general purpose of PISA is to determine the level of ability of students in reading, mathematics and science in various countries. According to [10] Indonesia's results in PISA are almost always ranked below. In 2000 Indonesia was ranked 39 out of 41 countries, in 2003 Indonesia was ranked 38 out of 40 countries, in 2006 Indonesia was ranked 50 out of 57 countries, in 2009 Indonesia was ranked 61 out of 65 countries. In 2012 Indonesia was ranked 64th out of 65 countries and lastly in 2015 Indonesia was ranked 62 out of 70 countries. In 2015 Indonesia has experienced an increase even though it is still in the low ranking category.

In solving a problem, a student according to [11] must have good problem-solving skills that can help him in the learning process. Based on this statement, it is clear that problem-solving skills play an important role in the learning process. Problem-solving can also be interpreted as a learning step that can train and improve problem-solving skills in learning activities and in solving a mathematical problem. In the learning process, students often assume that the final answer to a problem is the ultimate goal in solving a problem given by the teacher. In fact, the process of solving a problem given by the teacher is the main goal in problem-solving learning. In other words, each step of the work will be an assessment material by the teacher to see problem-solving abilities.

Problem-solving according to [12] is not a generic skill, but is a human activity that combines concepts and rules that have previously been obtained. If a student can solve a problem, then the student already has a new ability. The stages of problem-solving according to [13] are: (1) understanding the problem, (2) making a settlement plan, (3) executing the plan, (4) seeing or reexamining what has been done. Problem-solving is not only a form of abilities that apply the rules that have been mastered through previous learning activities, but problem-solving ability is a process to obtain higher abilities than previous abilities.

The problem-solving ability of each student is not the same. This statement can be seen from some results of previous research on the mathematical problem-solving ability of junior high school students. In research [14] entitled "Problem Solving Strategies in Solving Story Problems on the material for SPLDV class VIII students at Christian Middle School 2 Salatiga", concluded that 35.13\% of students did the understanding stage, $19.23 \%$ in the planning stage, and $45.64 \%$ in the solving stage, while $0 \%$ in the checking stage. This shows that not all students can do the stages of understanding, planning, solving and checking correctly. None of the students did the checking stage because there was no habituation from the teacher to re-check the results of student answers.

Based on the previous description of problem-solving, the notion of problem-solving ability is the ability to find ways to solve a problem by prioritizing appropriate procedures, strategies, and steps so that they can get the right answer. The difference with previous research is in the material to be tested, if in Emelia's research the material tested is a Two Variable Linear Equation System (SPLDV) in the form of story questions, then in this study, the material is sequences and series. Then in terms of education level in Emelia's research is the junior high school level while in this study the high school level. The purpose of the study was to analyze the mathematical problem-solving abilities of $\mathrm{XI}$ high school students in solving series and series questions. The ability that is expected to be mastered by students is the ability to solve mathematical problems properly and correctly in accordance with mathematical problem-solving indicators. By knowing the weaknesses or strengths 
of students' thinking processes, this research can be used as a basis for providing teacher assistance to students who experience problems in the process of solving mathematical problems.

\section{METHODS}

This research is a descriptive study that aims to describe the mathematical problem-solving ability of class XI students in solving problems of sequences and series, this is in line with the opinion [15] descriptive research is research that aims to determine the circumstances and conditions in which the results are described in the form of a research report so that it can find out the locations of student errors in solving series and series problems. Meanwhile, according to [15] Qualitative Approach is a research procedure that produces data in the form of written or spoken words from a person and actor being observed. The researcher chose class XI MIPA 1 as the sample class, but because the learning process at SMA was carried out with 2 shifts, shift B, totaling 12 people, was chosen as the research subject.

The research procedure to be carried out by the researcher is carried out in 3 stages, namely the preparation, implementation, and analysis stages. In the preparatory stage of the research procedure, what is done is to determine the location and time of the research, then make a test of mathematical problem-solving ability based on mathematical problem-solving indicators. From this preparation stage, the location for conducting the research was SMA and the research time determined was on Thursday, March 25, 2021, while the problem-solving ability questions that were used were validated questions, namely the 2018 National Exam questions package. A and B.

The analyzes that the researchers did include the analysis of the validity of the items, reliability analysis. The analysis is as follows:

\section{Analysis of Item Validation}

Validity is one of the important factors in determining the feasibility of the question instrument. Validity shows the compatibility between the items with the intention of being tested. To measure the validity of the items or the validity of the test items used product moment correlation with the following formula:

$$
r_{x y}=\frac{N\left(\sum X Y\right)-\left(\sum X\right)\left(\sum Y\right)}{\sqrt{\left\{N \sum X^{2}-\left(\sum X\right)^{2}\right\}\left\{N \sum Y^{2}-\left(\sum Y\right)^{2}\right\}}}
$$

\section{Information:}

$\mathrm{r}_{\mathrm{xy}}=$ correlation coefficient of an item/item

$\mathrm{N}=$ number of subjects (respondents)

$\mathrm{X}=$ score of an item/item

$\mathrm{Y}=$ total score

After each item is calculated the magnitude of the correlation coefficient with the total score, then the next step is to calculate the t-test with the following formula:

$\mathrm{t}_{\text {count }}=\frac{r \sqrt{n-2}}{\sqrt{1-r^{2}}}$

Information:

$\mathrm{t}_{\text {count }}=$ value tcount

$\mathrm{r} \quad=$ correlation coefficient result $\mathrm{r}$ count

$\mathrm{n} \quad=$ number of respondents

The $t_{\text {table }}$ value is obtained based on the $\mathrm{t}$-value table at a significant level $=5 \%$ or 0.05 for the twoparty test and degrees of freedom $\mathrm{dk}=\mathrm{n}-2$. The decision rules used are:

If $t_{\text {count }} \geq t_{\text {table, }}$, it means valid 
If $\mathrm{t}_{\text {count }}<\mathrm{t}_{\text {table, }}$, it means invalid

\section{Reliability Test}

A test is said to be reliable if the scores or values obtained are stable, anytime and anywhere or by whom the test is carried out, checked, and assessed. In this study, the researcher used the Cronbach Alpha formula as follows.

$r_{11}=\left[\frac{k}{k-1}\right]\left[1-\frac{\sum \sigma_{b}^{2}}{V_{t}^{2}}\right]$

Where:

$\mathrm{r}_{11} \quad=$ instrument reliability

$\mathrm{k} \quad=$ number of questions or number of questions

$\sigma_{b}^{2}=$ number of item variance / items

$V_{t}^{2}=$ total variance

The decision is based on the rule if the value of $r>0.7$ then it can be concluded that all items are reliable. An interpretation of the reliability coefficient using the following benchmarks:

Table 1. An Interpretation of the Reliability Coefficient

\begin{tabular}{cc}
\hline $\begin{array}{c}\text { Classification of the Reliability } \\
\text { Coefficient Big } \mathbf{r}\end{array}$ & Interpretation \\
\hline $0,80 \leq r \leq 1,00$ & Very high \\
$0,60 \leq r<0,80$ & Hight \\
$0,40 \leq r<0,60$ & Moderate \\
$0,20 \leq r<0,40$ & Low \\
$0,00 \leq r<0,20$ & Very Low \\
\hline
\end{tabular}

At the implementation stage, what was done was to give test questions of mathematical problem-solving abilities to class XI MIPA 1 students of SMA. Analysis stage, what is done at this stage is to analyze the test results and clarify the data obtained based on the problem-solving ability test and then draw conclusions from the research results. The number of samples was 25 people, but at the time of research, the learning process was limited face-to-face, meaning that the students of 1 class were divided into 2 parts. Where the sample is shift $\mathrm{B}$ with 12 students.

The instrument of this research is a test of the description of mathematical problem-solving abilities which consists of 4 description questions taken from the 2018 National Examination questions. The following is a test instrument to measure mathematical problem-solving skills used in this study.

1. Given an arithmetic sequence with $U_{3}=14$ and $U_{7}=34$. The sum of the first 23 terms of the sequence is?

2. The 7 th term of the geometric series $-54+36-24+\cdots$ is?

3. Given Un representing the nth term of a geometric sequence whose terms are positive. If $U_{7}-$ $U_{3}=24 \sqrt{2}$ and $U_{5}=3 \sqrt{3}$, what is the 6th term of the sequence?

4. A laying hen breeder records the number of eggs laid in 12 days. Every day the number of eggs produced increases by 4 pieces. If the first day the eggs produced amounted to 20 pieces, how many eggs are there for 12 days?

The results of students' answers were analyzed based on indicators of students' mathematical 
problem-solving abilities. The problem-solving indicators used are indicators according to opinion [14] stating that there are four levels of problem-solving abilities, namely (1) Very good, the criteria are able to understand the problem (write down what is known and asked), choose and use strategies clearly and rationally, make mathematical models and calculations correctly, re-examine the answers correctly, (2) Good with the criteria can understand the problem (write down what known and asked), select and use clear and rational strategies, make mathematical models with precise calculations, reexamine the answers with less precise, (3) Enough with the criteria of being able to understand the problem (writing what is known and being asked), choosing and using clear and rational strategies, making mathematical models and calculations less precise, less precise in making conclusions about answers, (4) Lack, the criteria can understand the problem (writing what is known and what is being asked), choosing and using strategies that are less precise and rational, making mathematical models and calculations less precise, and less precise in making conclusions about answers, (5) Very Lack, criteria cannot understand the problem (write down what is known and what is asked), does not choose and use clear and rational strategies, does not make mathematical models and calculations, does not complete solving tasks and draws conclusions. To determine the percentage of indicators of mathematical problem-solving ability on the material of sequences and series, the following formula is used.

$P=\frac{\text { total } \sum b}{\text { total } \sum b+\text { total } s} \times 100 \%$

Information:

$\mathrm{P} \quad=$ Percentage of indicators Mathematical problem-solving ability

$\sum b=$ Number of questions answered correctly (according to the KPMM indicator)

$\sum b=$ the number of questions answered incorrectly (according to the KPMM indicator)

To find out the percentage of students' mathematical problem-solving abilities, the researchers used the opinion of [13] as follows:

Table 2. Percentage of Students' Abilities

\begin{tabular}{cc}
\hline Percentage (\%) & Criteria \\
\hline $0 \leq P<20$ & Very low \\
$20 \leq P<40$ & Low \\
$40 \leq P<60$ & Medium \\
$60 \leq P<80$ & High \\
$80 \leq P<100$ & Very high \\
\hline
\end{tabular}

The criteria for students are said to have good mathematical problem-solving abilities if the percentage of errors made by students includes low and very low criteria or in points (1) and (2), while for the criteria students are said to have low mathematical problem-solving abilities if the percentage of errors that are carried out by students including the criteria of moderate, high and very high or points (3), (4) and (5).

\section{RESULTS AND DISCUSSION}

To see the validity of the questions obtained by comparing the value of $r$ count against $r$ table. If $r$ count $r$ table, it can be concluded that the question is valid In this study, the instrument used was a description test question which was analyzed according to the indicators of students' mathematical problem-solving. After being calculated using the anates application, the reliability value obtained is 0.495. If the value is $0.40 \mathrm{r}<0.60$ then the category of reliable items is sufficient/moderate. The questions given are questions that have been well-validated, namely the 2018 national exam questions, totaling 4 questions. The analysis that the researchers carried out on each question with all indicators 
of mathematical problem-solving ability.

After analyzing each question, it is then summarized as a whole. Based on the test results obtained from 12 students of class XI MIPA 1 SMA Negeri 1 Hulu Kuantan for question no. 1, the following data were obtained.

Table 3. Analysis of Problem-Solving Indicators in Question Number 1

\begin{tabular}{ccccc}
\hline \multirow{2}{*}{ Student } & \multicolumn{4}{c}{ KPPM Indicator } \\
\cline { 2 - 5 } & $\mathbf{1}$ & $\mathbf{2}$ & $\mathbf{3}$ & $\mathbf{4}$ \\
\hline 1 & 3 & 2 & 2 & 1 \\
2 & 2 & 2 & 2 & 1 \\
3 & 2 & 2 & 2 & 1 \\
4 & 2 & 2 & 2 & 1 \\
5 & 2 & 2 & 2 & 1 \\
6 & 3 & 3 & 2 & 0 \\
7 & 3 & 2 & 2 & 0 \\
8 & 1 & 2 & 2 & 1 \\
9 & 1 & 2 & 2 & 1 \\
10 & 2 & 3 & 1 & 1 \\
11 & 3 & 3 & 4 & 2 \\
12 & 0 & 2 & 2 & 1 \\
\hline Total & 24 & 27 & 25 & 11 \\
\hline Percentage $(\%)$ & 66,7 & 75 & 52,1 & 30,6
\end{tabular}

Table 3 shows that the mathematical problem-solving ability of students in question number 1 for each indicator, for indicators of identifying problems, understanding problems, the percentage obtained is $66.7 \%$ categorized as high. For indicators of planning problem-solving, stating and writing models or formulas that will be used to solve problems, the percentage obtained is $75 \%$ in the high category. The indicator of solving the problem according to the plan, performing arithmetic operations correctly the percentage obtained is $52.1 \%$ categorized as high enough, while the indicator evaluating, drawing conclusions from the answers obtained and re-checking the calculations obtained is $30.6 \%$ categorized as low.

Table 4. Analysis of Problem-Solving Indicators in Question Number 2

\begin{tabular}{ccccc}
\hline \multirow{2}{*}{ Students } & \multicolumn{5}{c}{ KPMM Indicator } \\
\cline { 2 - 5 } & $\mathbf{1}$ & $\mathbf{2}$ & $\mathbf{3}$ & $\mathbf{4}$ \\
\hline 1 & 0 & 0 & 4 & 0 \\
2 & 2 & 2 & 3 & 1 \\
3 & 3 & 0 & 2 & 1 \\
4 & 2 & 3 & 4 & 0 \\
5 & 0 & 2 & 2 & 1 \\
6 & 2 & 0 & 2 & 0 \\
7 & 3 & 3 & 4 & 2 \\
8 & 1 & 2 & 2 & 1 \\
9 & 2 & 0 & 2 & 0 \\
10 & 3 & 1 & 1 & 1 \\
11 & 3 & 3 & 4 & 2 \\
12 & 1 & 2 & 2 & 1 \\
\hline Total & 22 & 18 & 32 & 10 \\
\hline Percentage $(\%)$ & 61,1 & 50,0 & 66,7 & 27,8 \\
\hline
\end{tabular}

Table 4 shows that the mathematical problem-solving ability of students in question number 2 for each indicator, for indicators of identifying problems, understanding problems, the percentage obtained is $61.1 \%$ categorized as high. For indicators of planning problem-solving, stating and writing models or formulas that will be used to solve problems, the percentage obtained is $50 \%$ which is 
categorized as high enough. The indicator of solving the problem according to the plan, performing arithmetic operations correctly the percentage obtained is $66.7 \%$ categorized as High, while the Evaluating indicator, drawing conclusions from the answers obtained and rechecking the calculations obtained is $28.8 \%$ categorized as low.

Table 5. Analysis of Problem-Solving Indicators in Question Number 3

\begin{tabular}{ccccc}
\hline \multirow{2}{*}{ Student } & \multicolumn{4}{c}{ KPMM Indicator } \\
\cline { 2 - 5 } & $\mathbf{1}$ & $\mathbf{2}$ & $\mathbf{3}$ & $\mathbf{4}$ \\
\hline 1 & 0 & 0 & 3 & 0 \\
2 & 2 & 2 & 2 & 1 \\
3 & 3 & 0 & 2 & 1 \\
4 & 2 & 0 & 4 & 2 \\
5 & 2 & 2 & 3 & 1 \\
6 & 2 & 0 & 3 & 1 \\
7 & 3 & 3 & 4 & 2 \\
8 & 2 & 0 & 3 & 1 \\
9 & 2 & 2 & 2 & 1 \\
10 & 2 & 1 & 1 & 1 \\
11 & 3 & 3 & 4 & 2 \\
12 & 3 & 2 & 3 & 1 \\
\hline Total & 26 & 15 & 34 & 14 \\
\hline Percentage $(\%)$ & 72,2 & 41,7 & 70,8 & 38,9 \\
\hline
\end{tabular}

Table 5 shows that the mathematical problem-solving ability of students in question number 3 for each indicator, for indicators of identifying problems, understanding problems, the percentage obtained is $72.2 \%$ categorized as high. For indicators of planning problem-solving, stating and writing models or formulas that will be used to solve problems, the percentage obtained is $41.7 \%$ in the high category. The indicator of solving the problem according to the plan, performing arithmetic operations correctly the percentage obtained is $70.8 \%$ categorized as high, while the indicator evaluating, drawing conclusions from the answers obtained and rechecking the calculations obtained is $38.9 \%$ categorized as low.

Table 6. Analysis of Problem-Solving Indicators in Question Number 4

\begin{tabular}{ccccc}
\hline \multirow{2}{*}{ Student } & \multicolumn{4}{c}{ KPMM Indicator } \\
\cline { 2 - 5 } & $\mathbf{1}$ & $\mathbf{2}$ & $\mathbf{3}$ & $\mathbf{4}$ \\
\hline 1 & 2 & 2 & 3 & 1 \\
2 & 0 & 0 & 2 & 1 \\
3 & 3 & 2 & 3 & 1 \\
4 & 3 & 3 & 4 & 2 \\
5 & 2 & 0 & 4 & 2 \\
6 & 2 & 0 & 3 & 1 \\
7 & 3 & 3 & 4 & 2 \\
8 & 2 & 2 & 2 & 1 \\
9 & 2 & 0 & 2 & 1 \\
10 & 3 & 3 & 4 & 0 \\
11 & 3 & 3 & 4 & 2 \\
12 & 3 & 2 & 3 & 1 \\
\hline Total & 27 & 20 & 28 & 15 \\
\hline Percentage $(\%)$ & 75 & 55,6 & 79,2 & 41,7 \\
\hline
\end{tabular}

Table 6 shows that the mathematical problem-solving ability of students in question number 4 for each indicator, for indicators of identifying problems, understanding problems, the percentage obtained is $75 \%$ categorized as high. For indicators of planning problem-solving, stating and writing 
models or formulas that will be used to solve problems, the percentage obtained is $55.6 \%$ which is categorized as high enough. The indicator of solving the problem according to the plan, performing arithmetic operations correctly the percentage obtained is $79.2 \%$ categorized as high, while the indicator evaluating, drawing conclusions from the answers obtained and re-checking the calculations obtained is $41.7 \%$ categorized as high.

Table 7. Percentage of Answering Questions Correctly of Each Question

\begin{tabular}{clccc}
\hline KPMM & \multicolumn{4}{c}{ Percentage (\%) } \\
\cline { 2 - 5 } Indicator & $\mathbf{1}$ & $\mathbf{2}$ & $\mathbf{3}$ & \multicolumn{1}{c}{$\mathbf{4}$} \\
\hline I1 & 66,7 & 61,1 & 72,2 & 75 \\
I2 & 75 & 50,0 & 41,7 & 55,6 \\
I3 & 52,1 & 66,7 & 70,8 & 79,2 \\
I4 & 30,6 & 27,8 & 38,9 & 41,7 \\
\hline
\end{tabular}

Information :

I1 is the first Problem-Solving Ability indicator

I2 is the second Problem-Solving Ability indicator

I3 is the third Problem-Solving Ability indicator

I4 is the fourth Problem-Solving Ability indicator

In table 7 it can be seen that the ability to identify problems, understand problems is the highest in question no 4 compared to other questions. The ability to plan problem-solving, state and write models or formulas that will be used to solve problems is highest in question no 1 compared to other questions. The ability to solve problems according to the plan, perform arithmetic operations correctly is highest in question no 4 compared to other questions. The ability to evaluate, draw conclusions from the answers obtained, and recheck the calculations is the highest in question no 4 compared to other questions. Based on the average percentage of each question from all indicators, the results of calculating the percentage of achievement of mathematical problem-solving abilities can be seen in Table 8 below.

Table 8. Average Percentage of Each Problem-Solving Ability Indicator

\begin{tabular}{lcc}
\multicolumn{1}{c}{ Indicator } & $\begin{array}{c}\text { Percetage of } \\
\text { Correct } \\
\text { Answer (\%) }\end{array}$ & Criteria \\
\hline $\begin{array}{l}\text { Identify the problem, understand the problem } \\
\text { Plan problem-solving, state and write models or }\end{array}$ & $68,75 \%$ & High \\
$\begin{array}{l}\text { formulas that will be used to solve problem } \\
\text { Solve problems according to the Plan, perform } \\
\text { arithmetic operations correctly }\end{array}$ & $65,75 \%$ & Medium \\
$\begin{array}{l}\text { Evaluate, draw conclusions from the answers obtained } \\
\text { and re-check the calculations }\end{array}$ & $34,7 \%$ & Low
\end{tabular}

Based on the results of the percentage analysis in Table 8, it shows that the first indicator, namely identifying problems, understanding problems, the percentage is $68,75 \%$, with high criteria. The second indicator is planning problem-solving, stating and writing the model or formula that will be used to solve the problem, the percentage is $55.75 \%$ with moderate criteria. The third indicator is solving problems according to the plan, performing arithmetic operations correctly, the percentage is $67.2 \%$ with high criteria. The fourth indicator is evaluating, drawing conclusions from the answers obtained, and rechecking the calculation of the percentage is $34.7 \%$ with low criteria.

Based on the results of the analysis of the table as a whole, it can be seen that in general, the ability to solve mathematical problems in the material of sequences and series is still low where there 
are 3 indicators with the percentage of obtaining medium and high criteria, namely for indicators 1,2 and 3. Thus, it can be said that students still have difficulty in working on mathematical problemsolving ability test questions. The results of the analysis that students often do in solving it will be described in accordance with the students' problem-solving abilities in solving questions on the material of sequences and series on each question as follows.

Question Number 1

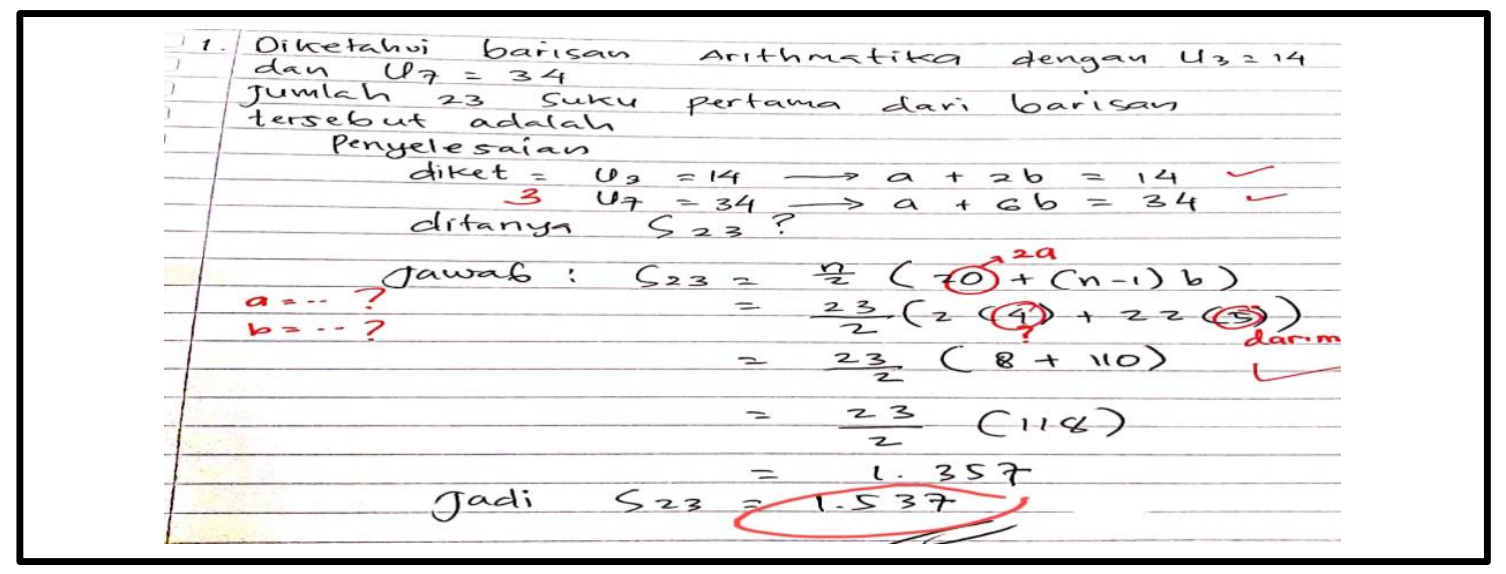

Figure 1. Answers of Student S-1

Figure 1 shows the answers of student S-1 getting a score of 3 on the 1 st indicator, getting a score of 2 on the 2 nd and 3 rd indicators. Sample no. 1 did not plan the completion process well, this can be seen in the answer, which is not seen from where the value of the first term (a) and is different (b) from the sequence. The 4th indicator gets a score of 1 because the conclusion given by sample number 1 is still not right, this is due to the lack of accuracy of students in drawing conclusions. This result is also different from the results of research [14] that the mathematical problem-solving ability of eighth grade students of SMP Negeri 1 Rambah Samo in solving mathematical problems in the flat-sided geometry material shows that students who have problem-solving skills at the very good level and are able to solve them in stages Polya in order. However, it is difficult to write down what is known and what is asked.

Question number 2

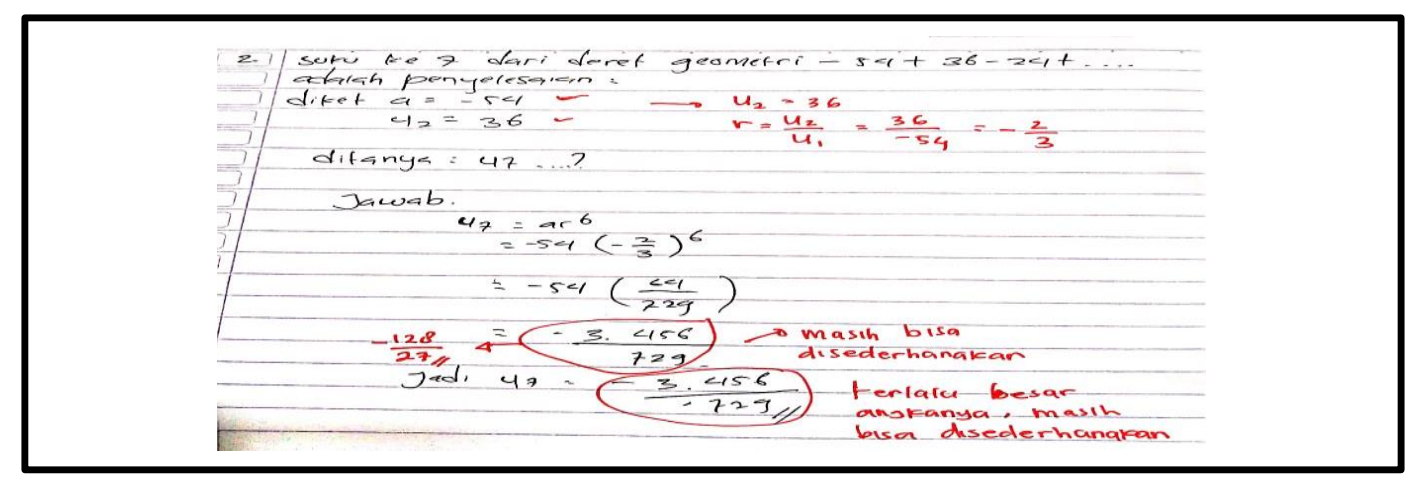

Figure 2. Answers of Student S-2

Figure 2 shows the answers of student S-2 getting a score of 2 on the 1 st indicator, students were able to understand the question even though it had not been made in detail so that it obtained a score of 2 on the 2 nd indicator, on the third indicator it got a score of 3 because students are not 
accustomed to simplifying answers, The 4th indicator gets a score of 1 because the conclusions are given by sample no. 2 are still not right.

Question number 3

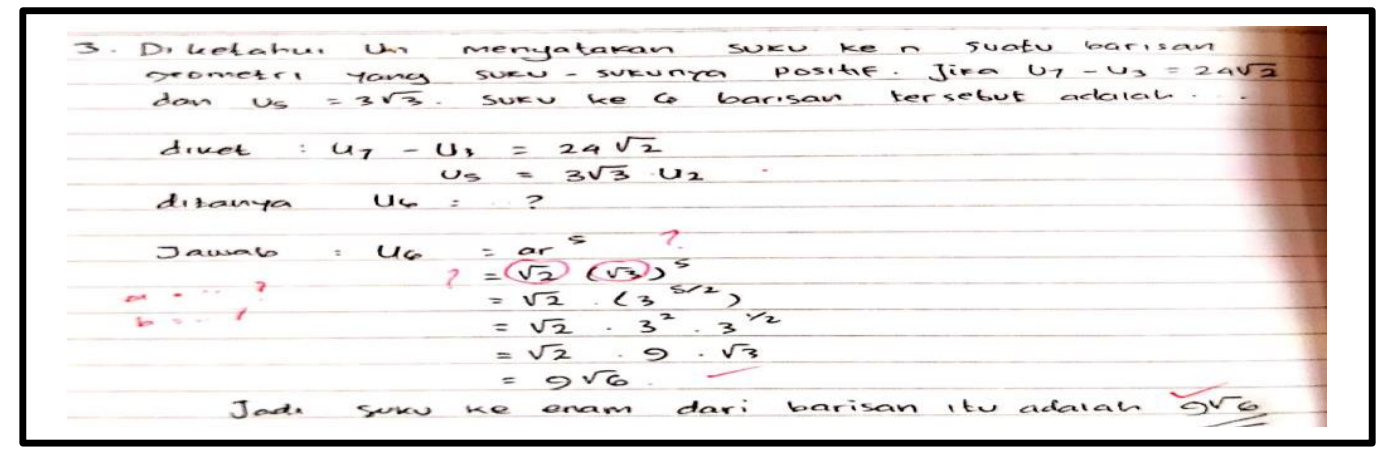

Figure 3. Answers of Student S-4

Figure 3 shows the answers of student S-4 getting a score of 2 on the $1^{\text {st }}$ indicator, obtaining a score of 0 on the $2^{\text {nd }}$ indicator because the sample did not plan the completion process, it can be seen from the sample answers that did not calculate the value of the first term and the difference in the sequence. A score of 4 on the 3rd indicator. The 4 th indicator gets a score of 2 because the conclusions are given by sample no. 4 are correct.

Question number 4

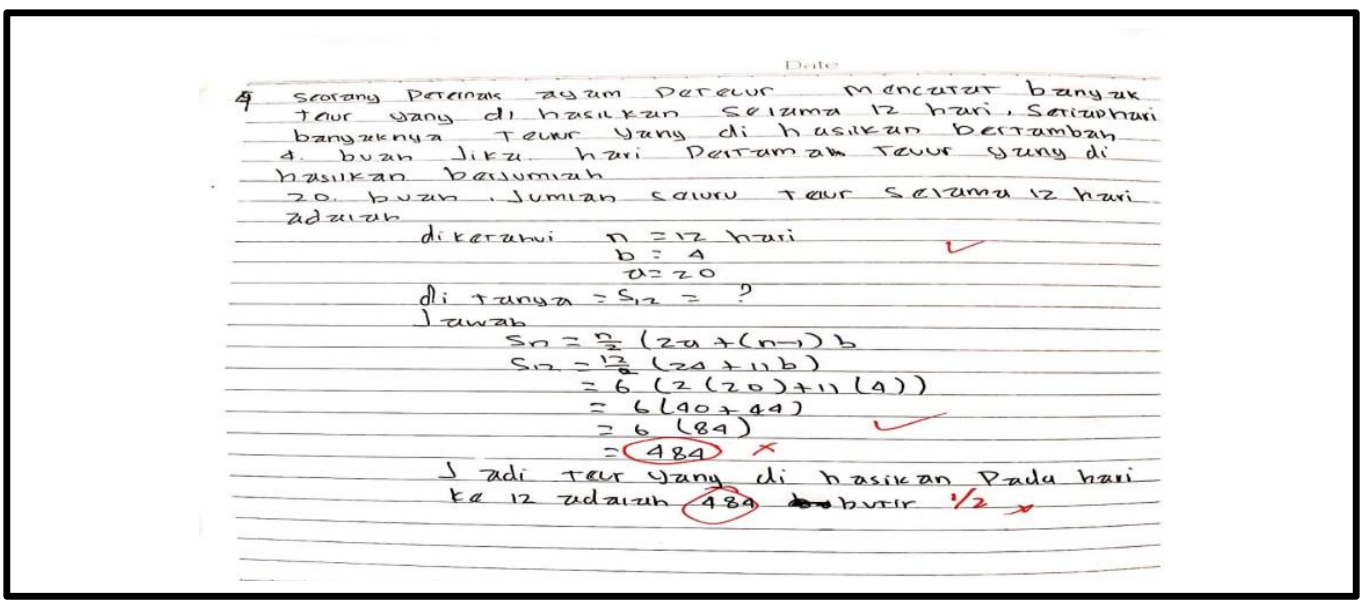

Figure 4. Answers of Student S-12

Figure 4 shows the answers of student S-12 getting score 3 on the first, second, and third indicators. In the third indicator the highest score was 4, but in the 12th sample, there was an error in the calculation of the final results. Likewise, the 4th indicator is also wrong in making conclusions caused by wrong calculations.

In this study, there are several factors that affect the level of problem-solving ability of each student, namely students who still do not understand the material for sequence and series and then have not done the correct steps in solving problem of test questions, this can be seen from students being able to do calculations but do not make plans correctly. Although students are able to make a mathematical model of a problem, they only make what is known from the problem without anymore detailed explanation so that students have not been able to transfer the knowledge they have acquired and have not been able to make connections from their prior knowledge. 
Based on the analysis conducted, the researcher found that of the four indicators of mathematical problem-solving ability, the lowest was the fourth indicator, namely evaluating, drawing conclusions from the obtained answers, and rechecking these calculations because students were not accustomed to checking the calculations carried out.

Based on the results of the analysis of the percentages of the five indicators, it can be seen that the indicators evaluate, draw conclusions from the answers obtained and recheck the calculations to obtain the lowest percentage, namely $34.7 \%$. The cause of the last low indicator is the habit of students not making conclusions at the end of the answer. Then for the second indicator Planning for problemsolving, stating and writing the model or formula that will be used to solve the problem, the percentage is $55.7 \%$ with quite high criteria.

The results of this study are almost in line with research conducted by [16] that students, for all abilities, have weaknesses in re-checking and drawing conclusions on the final answer. Likewise, the results of research [17] shows that overall based on the problem-solving ability indicator, the results are obtained for indicators of understanding the problem $(77.8 \%)$, making a resolution plan ( $0 \%)$, implementing strategies to solve problems (51.8\%) and explain or interpret the results of problemsolving $(14.8 \%)$. Students are low on indicators of making plans, and also on indicators of problemsolving.

\section{CONCLUSIONS AND SUGGESTIONS}

The results showed that students' mathematical problem-solving abilities were in understanding the problem, planning a solution, implementing a settlement plan, and checking back on all the steps that had been done. Based on the results of the overall problem analysis, it can be seen that generally the ability to solve mathematical problems on the material of sequences and series is still low, namely, there are 3 indicators with the percentage of obtaining medium and high criteria, namely for indicators 1, 2 and 3. Students still have difficulty in working on mathematical problem-solving ability test questions.

Lack of familiarity of students in solving a problem by using correct and appropriate steps or procedures is one of the reasons for the low mathematical problem-solving ability of students. Then students are not used to working on problem-solving questions which causes students to find it difficult to solve these problems. Therefore, students need to be trained in solving problems that have problem-solving abilities. Problem-solving abilities are not only used in the learning process but can also be used in students' daily lives.

Some suggestions that can be submitted based on the results of this study are as follows:

1. For researchers, research can be used as an additional insight into thinking.

2. For readers, the results of this study can be used as material for further research related to students' mathematical problem solving abilities on the material of sequences and series and are expected to pay attention to and overcome research weaknesses in order to obtain better results.

\section{REFERENCE}

[1] D. Nuryana and T. Rosyana, "Analisis Kemampuan Pemecahan Masalah Matematis Siswa SMK Pada Materi Program Linear,” J. Cendekia J. Pendidik. Mat., vol. 3, no. 1, pp. 11-20, 2019.

[2] Y.S. Siahaan and E. Surya, "Analisis Kemampuan Pemecahan Masalah Matematika Siswa SMP IT Nurul Fadhila Percut Sei Tuan," Medan, 2018.

[3] National Council of Teachers of Mathematics, "Principles and Standards for School Mathematics," 2000. [Online]. Available: https://www.nctm.org/Standards-andPositions/Principles-and-Standards/. [Accessed: 03-Mar-2021]. 
[4] Husna, M. Ikhsan, and S. Fatimah, "Peningkatan Kemampuan Pemecahan Masalah dan Komunikasi Matematis Siswa SMP Melalui Model Pembelajaran Kooperatif Tipe Think Pair Share (TPS)," J. Peluang, vol. 1, no. 2, pp. 81-92, 2013.

[5] T. Yuwono, M. Supanggih, and R. D. Ferdiani, "Analisis Kemampuan Pemecahan Masalah Matematika dalam Menyelesaikan Soal Cerita Berdasarkan Prosedur Polya," J. Tadris Mat., vol. 1, no. 2, pp. 137-144, 2018.

[6] H. E. T. Ruseffendi, Pengantar Kepada Membantu Guru Mengembangkan Kompetensinya dalam Pengajaran Matematika untuk Meningkatkan CBSA. Bandung: Tarsito, 2006.

[7] M. Juanda, R. Johar, and M. Ikhsan, "Peningkatan kemampuan Pemecahan Masalah dan Komnikasi Matematis siswa SMP melalui Model Pembelajran Means-ends Analysis (MeA)," J. Kreano, vol. 5, no. 2, pp. 105-113, 2014.

[8] F. Andayani and A. N. Lathifah, "Analisis Kemampuan Pemecahan Masalah Siswa SMP dalam Menyelesaikan Soal Pada Materi Aritmatika Sosial," J. Cendekia J. Pendidik. Mat., vol. 3, no. 1, pp. 1-10, 2019.

[9] Novitasari and H. Wilujeng, "Analisis Kemampuan Pemecahan Masalah Matematika Siswa SMP Negeri 10 Tangerang,” Prima J. Pendidik. Mat., vol. 2, no. 2, pp. 137-147, 2018.

[10] D. S. Mita, L. R. Tambunan, and N. Izzati, "Analisis Kemampuan Pemecahan Masalah Peserta Didik dalam Menyelesaikan Soal PISA,” Lentera Sriwij. J. Ilm. Pendidik. Mat., vol. 1, no. 2, pp. 25-33, 2019.

[11] Suratmi and A. S. Purnami, "Pengaruh Strategi Metakognitif Terhadap Kemampuan Pemecahan Masalah Matematika Ditinjau dari Persepsi Siswa Terhadap Pelajaran Matematika," UNION J. Ilm. Pendidik. Mat., vol. 5, no. 2, pp. 183-194, 2017.

[12] I. Purnamasari and W. Setiawan, "Analisis Kemampuan Pemecahan Masalah Matematis Siswa SMP pada Materi SPLDV Ditinjau dari Kemampuan Awal Matematika," J. Medives J. Math. Educ. IKIP Veteran Semarang, vol. 3, no. 2, pp. 207-215, 2019.

[13] Suraji, Maimunah, and S. Saragih, "Analisis Kemampuan Pemahaman Konsep Matematis dan Kemampuan Pemecahan Masalah Matematis Siswa SMP pada Materi Sistem Persamaan Linear Dua Variabel (SPLDV)," Suska J. Math. Educ., vol. 4, no. 1, pp. 9-16, 2018.

[14] N. Nadhifa, Maimunah, and Y. Roza, "Analisis Kemampuan Pemecahan Masalah Siswa pada Materi Bangun Ruang Sisi Datar,” Numer. J. Mat. dan Pendidik. Mat., vol. 3, no. 1, pp. 63-76, 2019.

[15] S. Arikunto, Prosedur Penelitian Suatu Pendekatan Praktik. 2010.

[16] Azizah, Maimunah, and Y. Roza, "Kemampuan Pemecahan Masalah Matematis Siswa pada Materi Peluang Berdasarkan Self-Regulated Learning (S-RL)," J. Rev. Pembelajaran Mat., vol. 4, no. 1, pp. 23-31, 2019.

[17] E. D. Adifta, M. Maimunah, and Y. Roza, "Analisis Kemampuan Pemecahan Masalah Siswa Madrasah Tsanawiyah Kelas VII pada Materi Himpunan," J. Kependidikan J. Has. Penelit. dan Kaji. Kepustakaan di Bid. Pendidikan, Pengajaran dan Pembelajaran, vol. 6, no. 2, pp. 340-348, 2020.

\section{BIOGRAPHY}

Resi Erni

Resi Erni has a history of education, namely: (1) SD Negeri 013 Banjar Guntung, (2) SMP Negeri 1 Kuantan Mudik, (4) SMA Negeri 1 Peranap, (5) Universitas Bung Hatta, Padang. Now, she is a teacher. Phone number: 082169342600. Email: resi.erni1744@grad.unri.ac.id 